\title{
Recycled Neuter Expletive Pronouns and the Nature of the Left Periphery: ell and Relatives Revisited*
}

\author{
Anna Bartra-Kaufmann \\ Universitat Autònoma de Barcelona \\ Centre de Lingüística Teòrica/Departament de Filologia Catalana \\ anna.bartra@uab.cat
}

Received: December 62011

Accepted: January 122012

\begin{abstract}
In this paper, we revisit two types of apparently Neuter Expletive Pronouns in Romance, namely Catalan ell, Spanish ello, EP ele, a.o., and the expletive neuter demonstratives aço, eso, esto, which have been argued in the literature to have an expressive value and to belong to the Left Periphery of the sentence. Our aim is to explore the relationship between expletive subjects and the Left Periphery in NS languages in a simple way. We base our investigations on the rich insights set up in the literature, and discuss if grammaticalisation could explain the shift from expletive subject to expressive marker. After briefly reviewing the properties of ell/ ello/ele, we show that it is unclear how they could fit into the current definition of grammaticalisation. We then review the common semantic properties of ello elements and neuter demonstratives, and argue that these elements anchor a speech act, a predication to the external situation. We explain how this property is encoded in a framework like the one of Hale \& Keyser's work. As for their syntactic properties, we claim that these elements belong to a reduced $\mathrm{C}-\mathrm{T}$ area.
\end{abstract}

Keywords: expletive subjects; discourse; left periphery; pronouns; demonstratives; ello; açò.

* This paper has been written thanks to the grants HUM 2006-13295-C02-02 from the Ministerio de Ciencia e Innovación, and 2009SGR-1079 from the Departament d'Economia i Coneixement of the Generalitat de Catalunya. I thank the editors of this volume Montserrat Batllori and Maria Lluïsa Hernanz for their encouragement, support and patience; M.Teresa Espinal, Jaume Mateu, Mar Massanell, M. Carme Picallo, Gemma Rigau, and the participants in the Workshop on Diachronic Syntax of the Centre de Linguïstica Teòrica (October, 2008) for their suggestions. I also to thank Clàudia Pons for pointing out to some very interesting data in Ferrer (1999), and to Ángel J. Gallego and Jaume Solà for their proofreading and improving the text. All remaining errors and shortcomings are attributable to me. 


\section{Table of Contents}

\section{0 . Introduction}

1. The data: pronominal and deictic elements as expletives and discourse markers in Romance varieties

\section{Previous analyses}

3. The grammaticalization hypothesis and the expressive value of ELLO
4. The discourse properties of neuter contrastive pronouns and deictic elements and its structural analysis

5. From expletive subject to the $\mathrm{CP}$ area

6. Conclusion

References

Databases

\section{Introduction}

The main goal of theoretical linguistics is the attempt to discover the general principles that govern the human Faculty of Language. In the Principles and Parameters Theory, the limits of parametric variation were considered the limits of possible grammars. A methodological discovery procedure to guarantee the empirical coverage of theoretical assumptions and principles was the search of negative evidence, which constituted a sort of Rosetta stone for the principles that were proposed. In this sense, the problem set by the analysis of earlier stages of language, i.e., diachronic linguistics, was the commitment to rely exclusively on positive data. Furthermore, diachronic data are problematic due to textual traditions ${ }^{1}$, literary styles, copy errors, and other well-known interferences that make it difficult to access the real language spoken in the historical period considered; in other words, it was considered quite difficult to know the ancient I-Language of individual speakers through the E-Language of which we had samples. That is to say that the bulk of evidence necessary to set the properties of UG and of particular grammars provided by the data stemming from ancient texts was considered clearly insufficient and not reliable. Therefore, the classical problem of establishing a borderline between core grammar and a marked periphery became apparently insurmountable with respect to old stages of language ${ }^{2}$.

Even more importantly, from a conceptual point of view, change inside the grammar is not to be discussed, ${ }^{3}$ since individual grammars are presumed to be established in the acquisition period of a child. The grammar being part of a human's mind-brain, grammars do not change: change is the illusory view obtained when one generation establishes a grammar different from the one of his direct ancestors.

However, by observing the type of differences that chronologically successive grammars show, some light can be shed on the general principles of the Faculty of Language, even more if systematic paths can be established in different cases.

1. See, e.g., Kabatek (2008).

2. For the classical notion of periphery, see Chomsky (1981: 9), Chomsky (1986: 147).

3. See Lightfoot (1999). 
The rise of new research methods, mainly due to the construction of reliable databases ${ }^{4}$ allows quantitative analyses to partially balance the absence of negative evidence and of the shortcomings mentioned.

Because of that, the discovery of scarce constructions ${ }^{5}$ poses interesting problems or questions, even if we can suggest a plausible explanation for their properties. Why does this construction disappear in later periods? Why did such a construction not succeed in later grammars? Was this construction usual among speakers or did it belong to a literary register, probably due to translational usages? From a strictly linguistic theoretical point of view, several lines of investigation can be pursued. Traditionally, peripheral structures ${ }^{6}$ obey markedness principles. In the diachronic research, external social factors such a preference in use, competition between simultaneous grammars, as well as statistical models have often been appealed to in order to explain the disappearance of an element ${ }^{7}$. An important line of research holds that in a given period different grammars can be competing until one of them wins and consequently a solution generalises. Conversely, the fact that some modern construction seems to have no clear ancestors in the old language poses also an intriguing problem.

One of these later cases is the subject of investigation of this paper. We want to consider the properties of some Romance neuter strong pronouns and demonstratives, which apparently act as neuter expletive subjects, but can be properly analysed as elements that bear discourse properties ( $\pi$-features). We will analyse their syntactic and semantic properties in order to show that these structures obey universal principles of structure composition.

We will start by considering examples as the ones from Old Catalan presented in (1) with the neuter strong pronoun ell:

$$
\begin{aligned}
& O C^{8} \text { ell està tot escrit en la Corònica de Aragó. } \\
& \text { it be.Pres. } 1 \text { all write.PP in the Chronicle of Aragon } \\
& \text { 'All that is written in the Chronicle of Aragon.' }
\end{aligned}
$$

(Despuig, Col·loquis, pp. 159, 1.17)

The logical subject is [tot $]$ and the predicate is [escrit en la Corònica de Aragó]; therefore, the only apparent possible analysis of $e l l$ is that of an expletive element. The same construction appears in other Romance languages, such as Italian (2) - (3),

4. In fact, corpora not only are a help in doing diachronic syntax, but in some cases the work with corpora is the only way to achieve some insights impossible with traditional ways (see McFadden (2010), Rinke \& Elsig (2010), Gries (2010) or Massanell (2009)).

5. Positivist philologists named the unique cases as hapax. We refer here to poorly attested ones.

6. In the above mentioned sense of Chomsky (1981) and (1986).

7. Kroch (1989, 2001), Pintzuk (2003).

8. From now on we use the initials for indicating languages: OC (Old Catalan), MC (Modern Catalan), CC (Contemporary Catalan), MBC (Modern balearic Catalan), OS (Old Spanish), MS (Modern Spanish), CS (Contemporqary Spanish), OI (Old Italian), CG (Contemporary Galician), EP (Contemporary European Portuguese), SDS (Santo Domingo Spanish). We use «Modern» in a quite idiosyncratic way to refer to XIXth C. and archaic XXth. C. constructions, since there is no other standard name for them. 
Spanish (4) - (5), or Galician (6) - (7), or Portuguese ${ }^{9}$ in different historical periods and with different extension and use:

(2) OI Egli è dunque inutile far indagini.

it be.Pres. 3 therefore useless do.INF inquiry

'So it is useless to do inquiries.'

(Martini, apud Migliorini 1966: 427)

(3) OI Egli era in questo castello una donna vedova.

ELLO be.Pst. 3 in that castle a woman widow

'In that castle, there was a widow.'

(Boccaccio, apud Fornaciari 1881/1974: 56)

(4) CS Ello es que era una vieja menudita.

ELLO is that be.PAST.3 a old+woman little

'There was a pretty old lady.'

(Azorín, Las confesiones de un pequeño filósofo, 89, apud Fernández Soriano 1999: §19.3.9, p. 1243)

(5) MS Ello has de casarte.

ELLO have+to.PRES.2 marry.INF.REFL.PR

'You should marry.'

(Rojas Zorrilla, Entre bobos anda el juego, III)

(6) C.Gal. El chovía.

ELLO rained

(Raposo \& Uriagereka 1990: 514)

(7) C.Gal. El parecía [que o patrón andaba canso].

ELLO seemed that the boss went-around tired

(Raposo \& Uriagereka 1990: 514)

There is a great deal of examples like (3), (4) or (6), in which this element occurs in impersonal existential sentences, and it clearly does not agree with the verb. Taking these cases into consideration, it was first analysed as an expletive. Raposo \& Uriagereka (1990), taking the contrast between (6) and (7) into account, on the one hand, and (8) and (9), on the other, conclude that ele and the postverbal subject are competing for the Nominative case assigned by INFL. The grammaticality of (9) is explained by the fact that the indefinite postverbal NP is assigned Partitive Case. ${ }^{10}$

9. For ease of exposition, from now on we will refer to all equivalent Romance forms (Cat. ell, Sp. ello, OIt. egli, EP. and Gal. ele as ELLO).

10. See Belletti (1988) for relevant discussion on this variety of Case. 
(8) *Neste garaxe, el estaban onte $\left[_{\mathrm{SC}}[\right.$ os coches] por amañar]. in-this garage it were yesterday the cars by to-repair

(9) El nacéu un rapaz cunha costela partida. it was-born a boy with-a rib broken

(Raposo \& Uriagereka 1990: 514-515)

As has been noticed in the literature, in some cases, ELLO takes the semantic value of an expressive peripheral discourse marker:

(10) MC Ell ha de ploure un dia o altre!

ELLO have.PRES. 3 to rain.INF one day or another

'It should rain one day or another!'

(DCVB, sv.ell)

(11) MBC - Madò Paula, parau taula. - Macià, ell no hi ha pa. Miss Paula set.IMP.2 table Macià ELLO not there has bread 'Ma' am Paula, lay the table / Macià, there is no bread.'

(Aguiló 1985: 197)

(12) $M B C$ Ell tu saps que crides!

ELLO you know.PREs.3 that shout-PRES.2

'You are shouting too much, you know?'

(Eiv. < DCVB) $)^{11}$

11. It is worth bearing in mind that ell is often pronounced in present-day language as [éj] in Balearic Catalan. This fact could lead us to assimilate it to $e i$, another discourse particle also found in other parts of the domain in sentences like (i) - (ii):

(i) $\mathrm{Ei}$, nostramo, la soldada!

EI boss, the pay-packet

'Hey, boss, pay us!'

(ii) Ey, aixins al menys ho diuen

(Maragall Enllà 47, DCVB)

EI so to+the least it.ACC say.PRES.6

'Well, at least that's what they say.'

(Oller Rur. Urb. 47, DCVB)

However, the intonational contour of the sentences containing $e i$ is different from the ones containing ell. Besides this fact, that we cannot show, ei, contrary to ell, can coexist with an overt complementizer, que:

(iii) Ei, que m'esquitxes picant així a l'aigua!

EI that me.Acc+splash kick.GER so in the+water

'You are splashing me by kicking on the water!'

(Massó Croq. 69, DCVB)

Other elements with properties similar to $e i$ are $e h$ and $e p$. All of them serve to attract attention of the listener:

(iv) Ep, que m'esquitxes!

EI that me.ACC+splash.PRES.2

'You are splashing me with water!' 
(13) MBC Ell ho ets, cansat, de ver!

ELLO it.ACC.Neut be.PRES.2 tired of true

'You are really tiring!'

(Menorcan Cat, Ferrer 1999: 21)

(14) MBC Ell guanyareu un bon jornal!

ELLO win.FUT.5 a good pay

'You will earn a good wage!'

(Menorcan Cat, Ferrer 1999: 67)

(15) EP Que ele eu gosto de socorrer (...) as pessoas, homem!

that EXPL I like of help.INF the people man

'I like to help people, man!'

(Carrilho 2005: 107)

(16) EP ele frio não está.

EXPL cold NEG is

'Cold it is not.'

(Carrilho 2005: 128)

This value of ELLO was already noticed by philological works, and it appears in dictionaries, studies on dialectology, and traditional grammars (Alcover \& Moll 1951, 1968; Baretti (1778), Lapesa (1996), Migliorini (1966), Veny (1999), a.o.), where it was analysed as an expressive element stemming from Latin neuter ILLUD $^{12}$. More recently, these facts have also been noticed by several formal linguists (Hinzelin \& Kaiser 2006, 2007, Hinzelin 2009, Remberger \& Hinzelin 2009, Carrilho 2003, 2005), who, after also exploring the hypothesis of an expletive lexical subject, arrived at the same conclusion and argued that it belongs to the left periphery of the sentence.

Several types of modal, focus, intensifying, topicalising particles exist in many Romance varieties. Most of them stem from grammaticalised adverbs, minimizers, and discourse markers. Interestingly enough, some of them show a halfway behaviour between a subject clitic and a left peripheral element. ${ }^{13}$ What is interesting about ELLO is that it is not a clitic, but a stressed Neuter Pronoun, and that its pragmatic and semantic properties are difficult to clarify.

12. Alcover \& Moll give the etymology ECCU ǏLLE.

13. We cannot go into the huge amount of data of several kinds of clitics, which in Romance varieties show properties that are between that of (expletive) subjects and that of left peripheral elements and the literature about them. It has been argued that some of these elements belong to the left periphery of the sentence, to a position higher than the one of the specifier of $\mathrm{T}$ (or, in former frameworks, AgrS) but lower than C. See, f.i., Munaro (2205), Munaro \& Poletto (2003), Poletto (2000), Rizzi (2004), Paoli (2007), Benincà \& Munaro (2010) among others. It is interesting for our purposes to consider the work by Longa, Lorenzo \& Rigau (1998: 154 ff), who report some Accusative Clitics that agree with the subject, as the ones in (i): 
Our point of departure will be the detailed description and the interesting insights of Hinzelin \& Kaiser (2006) and subsequent work, Hinzelin (2009), Remberger and Hinzelin (2009), and Carrilho (2003, 2005, and 2010, among other work). We will discuss some new points, mainly related to the pragmatic value of the element, the plausibility of a grammaticalization process, and the properties that relate subjects to elements of the Left Periphery. We will propose an analysis in terms of a predicative relationship that permits us to override the need for an alleged position in the Left Periphery. A guiding line of our analysis will have to do with the properties of Neuter Demonstratives introducing sentences. As stated by the authors mentioned, the existence and properties of $E L L O$ are related to other neuter pronouns as the ones exemplified in (17) - (21) $)^{14}$ :

(17) MBC Açò era un poble on hi havia dos veis it-Dem be.Past. 3 a village where CL.OBL have.PAST.3 two old 'There was a village where two old men lived.'

(Ferrer 199: 46)

(18) OC -Senyor, açò és stada una cosa Lord, it.DEM be.PASS. PRES.3 a thing 'Mylord, someting has happened.'

(Anon., Curial e Güelfa)

(i) a. ¡Aquí as veñen elas!

here CL-p.pl.fem.acc come-3p.pl. they-fem

'Here they come!'

b. ¡Aquí os veñen os veciños!

Here CL-P.PL.MASC.ACC come-3P.PL. the neighbors!

'Here come the neighbors!'

According to these authors, «This construction can only be used in present tense as a means of expressing a 'deixis ad oculos', using Bühler's (1934) term. Moreover, it has an exclamatory meaning.» Given the fact that these Clitics in Galician are incompatible with NEG markers, L,L \& R locate them in $\Sigma$ P (Laka, 1990). The construction with the deictic Locative alone, without the Clitic, is possible in Asturian and Spanish, as reported in (ii) ((xv) in L., L., \& R 1998: 161), and also in Galician (iii):

(ii) a. ¡Aquí vienen ellas! (Spanish)

here come they.FEM

'Here they come!'

b. ¡Aquí vienen elles!

(Asturian)

here come they.FEM

(iii) ¡Aqui veñen!

'Here they come!'

here come

'Here they come!'

(http://cfcereo.blogspot.com/2009/01/aqui-veen.html)

14. From now on in the text, we will refer to all (Old) Romance forms of the Neuter (Expletive)

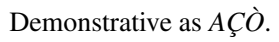


(19) OC

Açò és ver que nosaltres (..) havem sostenguda

it.Dem be.PRES.3 true that we sustain.PERF.4

la inhonesta e contínua freqüentació de Curial ab la Güelfa. the dishonest and continuous relationship of $\mathrm{C}$. and the $\mathrm{G}$.

'It's true that we supported the habitual and dishonest relationship between C. and G.'

(Anon., Curial e Güelfa)

(20) OC e açò era diyous.

and that be.PAST.3 Thursday

'And it was Thursday.'

(Crònica [Muntaner], Fol. 42rb, Linia: 15)

(21) OC Senyora Viuda, axò us hauré yo a molta gracia que

Lady widow that Cl.Dat.2 have.FUT.1 I at much mercy that

m'ho façau veure.

CL.Acc. 1 make.SUBJ.5 see.INF

'Milady Widow, I would be very grateful if you let me see...'

(Tirant, c. 254)

As for ELLO, we have seen that different Romance varieties share this element. The immediate question raised is if its properties are also identical. We are mainly interested in the questions summarized in (22):

a. Which are the properties shared by (expletive) subjects and «expressive» discourse markers? How can we account for these relations?

b. Can ELLO as a discourse marker be identified with one of the categories of the left periphery identified in Rizzi $(1997,2004)$ ?

c. Why are expressive discourse markers instantiated by personal pronouns and demonstrative deictic elements in some Romance varieties?

d. Can the expletive / expressive marker be the result of a grammaticalisation process?

The paper is organised as follows. In section 1, we present the data. In section 2, we refer to the important insights of previous analyses. In section 3, we briefly explore the possibility that the left peripheral ELLO be historically derived by grammaticalisation from the expletive one. In section 4 , we discuss the pragmatic and discourse value of $E L L O$ and $A C ̧ O$ and set several plausible hypotheses. We explore the possible relation of these elements to the notion of contrast. We discuss why deictic and contrastive pronominal elements can be used to fulfil this semantic value and we present an analysis based on principles stemming from Hale \& Keyser's $(1992,2002)$ work. In section 5, we explore the formal features of these 
elements and we put forward an analysis in a minimalist spirit under the Maximize Matching Effects Principle of Fortuny (2007). We also argue that its disappearance can be explained by appealing to the Subset Principle of DM (Halle \& Marantz (1993), Embick (2008), Embick \& Marantz (2008), a.o.). In section 6, we present the main conclusions of the work.

\section{The data: pronominal and deictic elements as expletives and discourse markers in Romance varieties}

As presented in the introduction, the first element noticed by its anomalous properties in a NLS is an apparent Neuter ${ }^{15}$ strong pronoun found in some late texts in Old Romance:

$$
\begin{aligned}
& \text { ell està tot escrit en la Corònica de Aragó } \\
& \text { it be.Pres. } 1 \text { all write.PP in the Chronicle of Aragon } \\
& \text { 'All that is written in the Chronicle of Aragon.' }
\end{aligned}
$$

(Despuig, Col-loquis, p. 159, 1.17)

As far as we know, in Old Catalan this element shows up only in three texts, all from the Renaissance. These texts are the Liber Elegantiarum of Joan Esteve $(1489)^{16}$, from which the examples in (24) are, the Vocabolari molt profitos per aprendre Lo Catalan Alamany y Lo Alamay Catalan (1502) from Barnils, which contains examples like (25), and Los Col-loquis de la insigne ciutat de Tortosa (1557), which contains a few examples like the ones in (26):

$$
\begin{aligned}
& \text { Ell es cosa pertinent al animo gentil demonstrarse } \\
& \text { ELLO be.PRES.3 thing adequate to+the spirit gentle show.INF } \\
& \text { graciós. } \\
& \text { pleasant } \\
& \text { 'A gentle soul has to be pleasant.' }
\end{aligned}
$$

b. Ell es necessari que una de aquestes coses

ELLO be.PRES. 3 necessary that one of these things $\mathrm{s}$ ['] esdevinga.

happen-PRES.SUBJ.3.Refl

'One of these things must happen.'

c. Ell es millor soportar tota cosa

ELLO be.PRES. 3 better endure.INF all thing

que esser subjecte als indignes than be.INF subject to+the.PL. worthless

'It is preferable to endure all bad things than to be governed by worthless people.'

15. Following previous analyses and descriptions, and according to its form in Spanish varieties, we suppose that ELLO is Neuter also in Catalan and other languages.

16. For a historical philological study of this work, see Moll (1982). 
d. Ell es esdeuengut un cas merauellos.

ELLO be.PRES. 3 happen.PCP a case marvellous

'It happened an extraordinary event.'

(25) a. $E l$ es plen.

ELLO be.PRES. 3 full

'It is full.'

b. $E l$ ha gran temps.

ELLO have.PRES:3 big time

'It's long time ago.'

(26) a. Ell vos pot parèxer increïble

ELLO CL.Dat.P1.2 can.PRES.3 seem.INF incredible

'It can seem incredible to you.'

This latter work furnishes two interesting cases with the pronoun in the feminine:

(27) a.

Ella és una cosa notable
Pron.Nom.3.Fem be.PRES.3 a thing remarkable
'This is a remarkable thing.'

b. Ella

és cosa maravellosa que

Pron.Nom.3.Fem be.PRES.3 thing extraordinary that

(...) se trobe tot (...).

CL.3.Refl find.PRES.3 all

'It is a wonderful thing that all is found...'

In (27a) ella is a subject agreeing with una cosa notable. But in (27b), ella, in spite of the fact that it agrees with cosa meravellosa, corefers with the extraposed sentence [que dins d'un mateix terme se trobe tot lo que sol ésser dins un regne].

We find similar cases in Italian:

(28) MI Egli piove. (Meyer-Lübke, 1899:56, apud Hinzelin, 2006:50)

ELLO rains

'It rains.'

The first references we know are the ones in Baretti (1778), who refers to it as an expletive particle ${ }^{17}$ and Fornaciari (1881), who considers egli and its shortened

17. «We say very often egli névica, egli grándina, egli piove, egli baléna; and still oftener e' névica, e'grandina, e'piove, e'baléna. E' is, in this case, a contraction of egli; and egli is not to be considered in such a case a pronoun, but rather as an expletive particle.» (Baretti 1778: 45). 
version è as riferiti ad un concetto astratto, ad una proposizione o sentenza ${ }^{18}$. See the example in (29), from Fornaciari (1881), where egli seems to corefer with caldo veruno
Anzi non fa
egli caldo veruno.
in-fact NEG make.PRES.3 ELLO hot no-one
'In fact, it isn't hot.'

(Boccaccio, apud Fornaciari (1881/1974: 56))

In several Spanish varieties, ello survived until recently. In literary Peninsular Spanish it survived at least until the XVIII C. Lapesa (1996) ${ }^{19}$, and more recently, Hinzelin \& Kaiser $(2006,2007)$ have shown that it survived in Santo Domingo Spanish:

(30) $M S$

Ello era tarde. (Moratín, El barón) ${ }^{20}$

ELLO be.PAST.3 late

'It was late.'

(31) $M S$

Ello hay de por medio no sé qué

ELLO have+y of by middle NEG know.PRES:1 what

papel de matrimonio.

paper of marriage

'There is in between some marriage certificate.'

(Moratín, La escuela de los maridos)

(32) SDS
Ello hay
dulce de ajonjolí.
ELLO have.PRES.3+y sweet of sesame
'There is sesame candy.'

18. «EGLI ED E' IN SENSO NEUTRO. Egli, e così pure le forme proclitiche gli ed $e$ ', si costruiscono anche molto spesso col verbo, riferiti ad un concetto astratto, ad una proposizione o sentenza. P.es. Egli era in questo castello una donna vedova. Boccaccio. - E s'egli è ver che tua potenza sia Nel ciel si grande ecc. Petrarca.- O figliuola mia, che caldo fa egli? Anzi non fa egli caldo veruno. Boccaccio.- S'io potessi parlare al re, èmi da il cuore ch'io gli darei un consiglio ecc. Boccaccio.- [...] Gli è cosa molto difficile voler ... riconoscere gli uomini morti già dugento anni fa. V. Borghini.- Gli è perchè le ho visate io quelle faccie. Manzoni.» (Fornaciari 1881: 55-56).

19. El neutro ello se conserva en Santo Domingo y Puerto Rico como sujeto impersonal («ello es fácil llegar», «¿ello hay dulce de ajonjolí?»), como refuerzo de afirmaciones y negaciones («¿pero tú no estuviste? -Ello sí»; «parece que va como triste el amigo. -Ello no»), como expresión de vago asentimiento (¿quieres bailar? -Ello» ‘bueno’) o evasiva («¿qué remedios... han administrado ustedes al niño? -Eyo, dotol») [The neuter ello still exists in Santo Domingo and Puerto Rico as an impersonal subject («ello es fácil llegar»-ello is easy to-reach-, « ¿ello hay dulce de ajonjolí?»-ello is-there sweet of ajonjolí), as a reinforcement of affirmations and negations («ipero tú no estuviste? -Ello sí» -but you not were-there - ello yes; «parece que va como triste el amigo. -Ello no»-it-seems that he-goes like sad the friend -ello no), as an expression de vague assent (¿quieres bailar? -Ello» 'bueno' -you-want to-dance - ello OK) o excuse («¿qué remedios... han administrado ustedes al niño? -Eyo, dotol» -what remedies have administered you to-the child -ello doctor).] Lapesa (1996)

20. Examples (28) to (35) are from Hinzelin \& Kaiser (2006). 
(33) SDS Ello dicen que no es muy buena.

ELLO say.PRES.6 that NEG be.PRES. 3 very good.FEM

'They say that she is not very good.'

(34) SDS Ello hay muchos magos este año.

ELLO have.PRES.3 many magicians this year

'There are many magicians this year.'

(35) SDS Ello no sería malo estudiar.

ELLO NEG be.COND.3 bad study.INF

'It wouldn't be bad if we study.'

As we saw in the introduction, other Romance languages, such as European Portuguese, Galician, several Balearic Catalan varieties (Mallorcan, Menorcan, Eivissian) show parallel cases. Hinzelin \& Kaiser (2006) also report an Asturian example:

(36) Ast.: Ello yera una vegada un capiellín colloráu

ELLO was one time a little-hat red

'Once upon a time, there was a red little hat.'

In Occitan, the expletive shows up only as a demonstrative, but there are very few examples:

(37) Occ.: Aquò plou (Alibert, 2000:283, ibid.) $)^{21}$

that rains

'It rains.'

Carrilho (2003, 2005, among others) has thoroughly examined the presence of ele in European Portuguese.

In Table 1, we summarize the environments in which expletive ELLO can appear. $^{22}$

Table 1. Uses of the variants of Romance expletive-expressive ELLO (First Version)

- Impersonal existential sentences that begin a narration.

- Atmospheric predicates.

- Impersonal pronominal sentences.

- Sentences with extraposed clauses.

- Copular sentences with a postverbal adjective and clause.

- Unaccusative predicates.

21. In coloquial French, besides Il pleut / neige / grêle it exists Ça pleut / neige / grêle. Manente (2007), following Grevisse \& Goosse (1993) argues that this demonstrative is related to the locative çà and is licensed by the unaccusative - directional valence of weather predicates.

22. See also Carrilho (2005, Ch. 2). 
The common view among researchers is that there is no plausible explanation within current frameworks without introducing ad hoc modifications in the basic tenets of the theory. ${ }^{23}$ This in fact requires introducing some degree of exceptionality.

In another set of data, like the ones in (38) to (44), ELLO shows what Hinzelin \& Kaiser (2006) call its «expressive meaning», following the classical philological tradition, which considered it an exclamative marker:

(38) EP Ele há cada uma!

ELLO has such one

'There are such things!'

(Carrilho 2003: 2)

(39) EP Ele quem se casa saõ eles!

ELLO who SE marries are they

'THEY are WHO will marry!'

(Carrilho 2005: 129)

(40) EP Ele vamos embora!

ELLO go-PRES-SUBJ-1-PL away

'Let's go!'

(41) EP -Vás trabalhar? -Ele não!

go-PRES.sg work-INF ELLO NEG

'Are you going to work? -No!'

(42) $M B C$ Ell tanmateix és gros, això!

ELLO however be.PRES.3 big that

'That's certainly terrible!'

(43) $M B C$ Majoral, ell ja és migdia!

foreman, ELLO already be.PRES.3 noon

'Foreman, it's noon!'

(Aguiló, 67)

(44) $M B C$-¡Tornar-lo! Ell me'n gordaré give-back+CL.Acc.Masc.Sg ELLO CL.Acc.1+CL.Gen escape.FUT.1 com de caure!

like of fall.INF

'Give it back? I won't by any means!'

In all these cases, ELLO shows an expressive meaning. In (38) - (40), it behaves like an exclamative marker. In (41) - (44), it is used in a replica in which the speaker explicitly contradicts the presuppositions of its partner in the dialog. In (45), it behaves like a marker of emphatic affirmative polarity:

23. See Raposo \& Uriagereka (1990). 
(45) Taxi-driver: -Vamos pela Miguel Bombarda?

'Shall we go by Miguel Bombarda Avenue?'

Passenger: $\quad$-Não sei. Tenho alguma pressa. Tenho de lá estar às 10h.

'I don't know. I am in a hurry. I have to be there at ten o'clock.'

Taxi-driver: -Bem, ele pelo tempo dá...

well EXPL for.the time does

[ > pelo trânsito já não sei]

for.the traffic already not know-PRES.1

'Well, as for the time we have, it will do.' [ >> as for the traffic, I don't know...]

(Carrilho 2005: 128)

We restate Table 1 as in Table 2.

To end this section, in Table 3, we summarize the main uses of ELLO we have noticed $^{24}$.

Table 2. Uses of the variants of Romance expletive-expressive ELLO (Second Version)

\section{A. Apparently expletive subject}

a. Impersonal existential sentences that begin a narration.

b. Atmospheric predicates.

c. Impersonal sentences.

d. Sentences with extraposed clauses.

e. Copular sentences with a postverbal adjective and clause.

f. Unaccusative predicates.

B. Expressive element of the Left Periphery

a. Exclamative marker.

b. Marker of a counterpressupositional replica.

c. Emphatic affirmative polarity.

Table 3

\begin{tabular}{|c|c|c|c|c|c|c|c|c|}
\hline \multirow{6}{*}{ 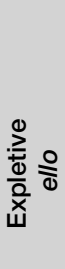 } & & $\begin{array}{c}\text { Old } \\
\text { Catalan }\end{array}$ & $\begin{array}{l}\text { Modern } \\
\text { Balearic }\end{array}$ & $\begin{array}{l}\text { Classical } \\
\text { Spanish }\end{array}$ & $\begin{array}{c}\text { Dominican } \\
\text { Spanish }\end{array}$ & $\begin{array}{l}\text { Eur. } \\
\text { Port. }\end{array}$ & Galician & Sardinian \\
\hline & Meteo & + & + & $?$ & + & + & + & $?$ \\
\hline & Exist. & + & + & + & + & + & + & $?$ \\
\hline & Extrap. & + & + & + & + & + & & \\
\hline & Unacc. & + & $?$ & + & + & + & + & $?$ \\
\hline & $b e+A$ & + & + & + & + & + & $?$ & $?$ \\
\hline \multirow{4}{*}{ 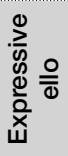 } & Question & - & - & & + & & $?$ & + \\
\hline & Neg answ. & + & + & + & + & + & $?$ & \\
\hline & Excl. & $?$ & + & + & + & + & + & + \\
\hline & Emph. Pol. & $?$ & + & + & + & + & $?$ & $?$ \\
\hline
\end{tabular}

24. We include the uses of ELLO in Sardinian noticed by Remberger \& Hinzelin (2009). 


\section{Previous analyses}

As we mentioned in the introduction, there are basically two mainstream explanations for ELLO. Raposo and Uriagereka (1990), in the line of grammarians like Baretti (1778) and Miglorini (1966), treated it as an (exceptional) expletive subject. The other line of reasoning is that of Hinzelin \& Kaiser (2006), Hizelin \& Remberger (2009), and Carrilho (2003, 2005), who argue that ELLO in Balearic Catalan, Santo Domingo Spanish, and European Portuguese is a discourse marker which belongs to the Left Periphery of the sentence.

Hinzelin \& Kaiser (2006) convincingly argue against an expletive subject analysis of $E L L O$ in Dominican Spanish and in Balearic Catalan. The arguments they adduce are the following: (a) it is not obligatory in expletive contexts; (b) it appears in sentence initial position; (c) it can be clearly interpreted as a discourse marker. Carrilho (2003) goes one step further and explicitly proposes that ele «lexicalizes the left-peripheral projection of Force-P (...) independently of the type of element appearing on the subject position». Hinzelin \& Remberger (2009) also argue for a very high position for Sardinian ello. Carrilho (2005) argues for two peripheral ele in $\mathrm{EP}^{25}$. One of them is a phrasal element, which is in [Spec, ForceP]. See (46) from Carrilho (2005: 247):

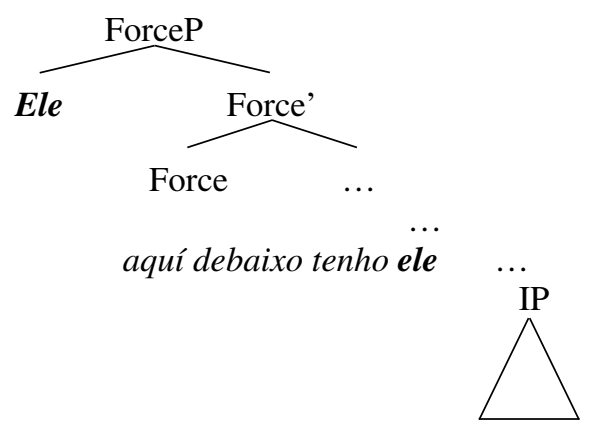

The other one is a postverbal ele, which occupies a much lower position in the sentence, and which is much more restricted. Following Carrilho, this element is a head of an Evaluative Phrase, below ForceP. The verb rises to [Spec, EvalP]; this is the reason why it appears postverbally. The two positions are necessary since there is a possibility of the two ele co-occurring in $\mathrm{EP}^{26}$ :

25. Richards \& Biberauer (2005) argue that expletives can only be merged in Phase heads, $\mathrm{C}$ and $v$, not in T. In that picture, the fact that EP ele appears in postverbal position follows naturally.

26. Other cases have been brought forward in the literature of elements of the C-T field that look the same, but are in fact homonymous. Cardinaletti \& Repetti (2010) argue for two types of preverbal vowels in Piacentine dialects: one as a Spell-Out of the Q+Foc head of the CP layer, and the other a declarative element of a FP of the IP layer. 
(47) Ele aquí debaixo tenho ele assimumas pias para os pequeninos, EXPL here below have-1 EXPLthus some sinks for the small.ones par lá comerem, for there eat-INF-3PL

'Here, under this, I have some sinks for the small ones, for them to eat there.'

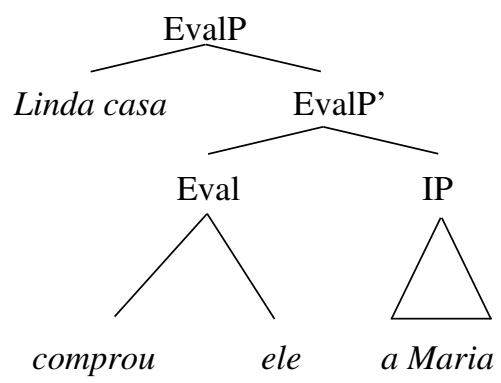

We will follow this insight by Carrilho, but we will dispense with the need for dedicated positions for it.

\section{The grammaticalization hypothesis and the expressive value of ELLO}

Both in the positivist philological literature and in more recent frameworks, like functionalism and generativist minimalism, discourse markers are posited to stem from former semantically contentful elements by the processes of semantic bleaching and phonological shortening, i.e., by grammaticalization. Moreover, following Roberts \& Roussou (2003, and subsequent work), as well as van Gelderen (2004a/b, 2006, 2008), grammaticalization implies that the difference between a former grammar and a subsequent one is that the non grammaticalized element had to undergo internal merge (i.e. Move) whereas the grammaticalized element gets merged by external merge (i.e. simply Merge). The common view, nevertheless, is that the motivation for the shift from Internal Merge to External Merge is the loss of interpretable formal features (FF). It is also assumed that the grammaticalized element is a head whereas its predecessor was phrasal ${ }^{27}$.

At this point, let us assume, for simplicity, that the expressive left peripheral use of ELLO has a $\pi$-feature [+contrast] to be Probed in some projection of the extended C domain (at the Left Periphery). Several possibilities come to mind. We synthetize them in (49):

27. We present Grammaticalisation Theory in its classical form, under a checking theory of FFs. However, it is not clear if this picture fits in a Probe-Goal system. These questions go far beyond the scope of this work. 
(49) a. The grammaticalized element has lost some of its valued FFs, namely Case, and it cannot value all the $[u \mathrm{~F}]$ of its Probe. This fact would explain the behaviour of demonstratives and personal pronous when grammaticalized as expletives in the cases with a postverbal element. The expletive would be probed by the EPP feature of T and the extraposed element would establish a Long Distance agreement with $\mathrm{T}$.

b. ELLO or the corresponding demonstrative has lost all the $\phi \mathrm{F}$, but it keeps its [+contrast] $\pi$-Feature. Therefore, it is unable to be probed by any feature on $\mathrm{T}$. It can only be probed by a $\pi$-feature $([+$ contrast $])$ in $\mathrm{C}$. This would explain the next stage: it has become a peripheral expressive marker.

c. The element has lost all its valued FFs. Therefore, since it only has unvalued features, it cannot be lexical, but the realization of a functional head, namely, $\mathrm{C}, \mathrm{T}$ or $v$. In this later case, ELLO would only have a $\left[u \mathrm{~F}_{\text {contrast }}\right]$. However, the unvalued contrast feature would have to probe some element with a valued $\left[v \mathrm{~F}_{\text {contrast }}\right]$ feature. This possibility is not clearly arguable on an empirical basis.

If we view the three possibilities in (49) as three stages in the grammaticalization cline, this could be a plausible explanation of part of the behaviour of Neuter

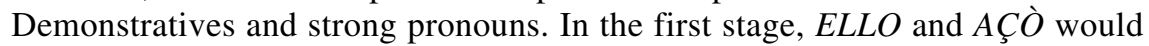
have some valued features to be probed by $\mathrm{T}$, such as Case or EPP. Later on, ello is unavailable to value $[u \mathrm{EPP} / \phi, \mathrm{T}]$. T is rescued by Long Distance Agree with the associate (postverbal NP, DP or CP). Ello is probed by $\left[u \mathrm{~F}_{\text {Contrast }}\right]$ in C.

However, we will pursue a slight different path. First, it is not clear, at least from a semantic-pragmatic view, that the properties of ELLO vary over time. Second, it is unclear what the phonological reduction and semantic bleaching of ELLO could be. Third, how come an Exclamative or Force feature would develop?

Let us assume with Rigau (1988) and Mayol (2010) that strong pronouns (as well as demonstratives) in Catalan ${ }^{28}$ have an emphatic or contrast meaning. We assume that this is instantiated in a valued $\pi$-feature.

In that sense, the properties of ELLO at different periods are the same. In both uses, as an apparent expletive subject and as a peripheral expressive element, ELLO introduces a propositional element and its semantic and pragmatic function is to bring this propositional content to the attention of the listener ${ }^{29}$.

28. We want to be cautious and restrict our assertion to Catalan, even if probably in Spanish and other Romance Languages like Italian strong pronouns also have a contrastive value. One important difference between Catalan and Spanish lies in the use of strong pronouns in PPs; since in Catalan there exist weak pronominal clitics with Genitive -Partitive and Oblique Case, strong pronouns selected by a $\mathrm{P}$ are only legitimate if they refer to a [+human, +contrastive] discourse linked element:

(i) *Va anar a buscar un llibre i va tornar amb ell sota el braç (she)went looking for a book and came bach with it/him under his arm

(ii) Va anar a Barcelona a veure el pare i va tornar amb ell (she) went to Barcelona to see her father and came back with him

29. See Diessel $(1999,2006)$ and references therein. According to Diessel, one of the functions of demonstratives is «to coordinate the interlocutor's joint attentional focus.» (Diessel 2006: 469). 
What remains to be clarified is whether it has the same formal features in both uses. Under Roberts \& Roussou's view on grammaticalization, we would have to assume that in its alleged way from an expletive subject to a Force marker, ELLO suffered two changes:

(50) a. A change from phrasal to $\mathrm{X}^{0}$

b. The loss of FFs (Nom or EPP)

The proposal in (50) would explain the fact that ELLO, deprived of the FFs that made it an available probe for $\mathrm{T}$, raises further to a higher projection in the tree: $\Sigma$ P /PolP, Force P, or FocP.

Things, however, do not fit so easily in that picture and we argue that this line of reasoning suffers from various handicaps and shortcomings.

First, ELLO is Neuter (Catalan, Spanish, and Sardinian) or Masculine, the unmarked form, (European Portuguese and Galician). That means that it has no Gender Feature and no Person Feature ${ }^{30}$ (as the 3rd. person is the morphological default value), and it does not refer to individuals. That is the reason why it can corefer with extraposed sentences and why it can appear as an expletive subject in impersonal sentences. It keeps a contrastive or emphatic value, which has to be probed by a $\pi$-feature from a higher position in the Left Periphery. Which is then the difference between a contrastive Neuter expletive subject and an intensifier Neuter element in the Left Periphery? Both are nonreferential elements, both lack a Person feature, both are intended to pick up the hearer's attention to the propositional content it that is conveyed by the sentence, i.e., both have a contrastive value.

Moreover, Heine \& Song (2011) show that personal pronouns present a challenge to the classical theory of grammaticalization. Following these authors, the main sources of personal pronouns are the ones in $(51)^{31}$ :

(51) (a) Spatial deixis (demonstratives)

(b) Nominal concepts

(c) Intensifiers

Grounding on a wide range of crosslinguistic data, they argue that

«Crosslinguistically there are a number of languages where intensifier ('self') or identity forms ('the same') have given rise to personal pronouns, while there is so far no evidence for a development in the opposite direction.» (Heine \& Song 2011: 13, emphasis $\mathrm{AB}-\mathrm{K})$.

30. See Harley \& Ritter (2002), and Pomino \& Stark (2008, 2009, 2010).

31. Heine \& Song (2011: 9). 
ELLO seems to move in this unattested opposite direction: from a personal pronoun to an intensifier. ${ }^{32}$ Our claim is that there is no such path: both uses of ello have the same features and properties. The only clear property that could be an index of a grammaticalization process would be the loss of individuation properties or even the referring ability ${ }^{33}$. In order to make some suggestions about the properties of ELLO, we will compare them briefly with the ones of the Neuter Demonstratives esto and eso and their old variants (e.g. OC. ço, açò, assó), the

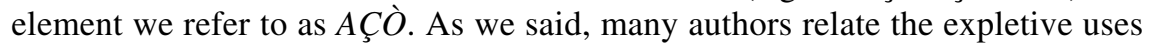
of ELLO and esto, això, and their relatives. In the next section, we briefly discuss the properties of these Neuter demonstratives.

\section{The discourse properties of neuter contrastive pronouns and deictic elements and its structural analysis}

Diessel (1999: 6 and 92-114) and Diessel (2006), following previous work on the pragmatics of demonstratives, establish a basic division between exophoric and endophoric uses of demonstratives. Exophoric demonstratives are «demonstratives that are used with reference to entities in the speech situation» (Diessel 1999: 93). Endophoric uses can be divided into anaphoric, discourse deictic, and recognitional. We are especially interested in discourse deictic uses. Demonstratives used with this purpose «link the clause in which they are embedded to the proposition to which they refer» (Ibid, 93). Consider the sentences in (52) and (53):

$$
\begin{aligned}
& \text { OC digueren-los que açò era costuma d'ells: que (...) } \\
& \text { say.Past.6+them.Dat that DEM be.Past.3 habit of+they that } \\
& \text { despertaven los ferres de les lances. } \\
& \text { awake.PAST.6 the irons of the spears } \\
& \pm \text { 'They told them that it was usual for them to encourage the spears.' } \\
& \text { (Crònica [Muntaner], Fol. 103vb, Linia: 17) }
\end{aligned}
$$

(53) $O C$ dién -los que açò era malfet que semblants coses say.GER+them.DAT that DEM be.PAST.3 wrong that such things fossen consentides

be.SUBJ.6 permit.PstP '...saying that is was wrong to permit such things.'

(Epistolari de la València Medieval_I (4/5), Carta 148, Linia: 52)

32. Silva-Villar (2004) argues that «No language has developed expletive topics from expletive subjects: *Subject-Expl $>$ Topic-Exp, because the historical sequence is pro-drop $>$ Topic-Exp $>$ Subject-Exp (Faarlund 1990)».

33. This assertion can be challenged in view of the cases where $E L L O$ heads a replica to a previous sentence. The limits of this paper do no permit us, however, to discuss the reference properties of $E L L O$. We leave this issue for further investigation. 
The examples in (52) and (53) clearly show the well known stage of a deictic demonstrative preceding a clause, a use that in many languages has led to the development of complementizers via grammaticalization. ${ }^{34}$

Other demonstratives that look like expletives, but are in fact resumptive anaphoric or cataphoric, are the ones in (54) - (57):

(54) OC trobà -li

lo cor tan batent, que açò

find.PAST.+CL.Dat.Sg the heart so much beat.GER that DEM:neut

era gran maravella;

be.PAST. big wonder

' $(\mathrm{He})$ realized that her heart was beating so heavily that he became astonished.'

(Curial e Güelfa, p. 82, Linia: 11)

(55) OC E tantes riqueses foren trobades (...)

and so many treasures be.PAST.6 find.PP.Fem.Plur

que assò fou gran mervella de veura.

that DEM.Neut be.PAST.3 big wonder of see.INF

'And so many treasures were found that is was wonder ...'

(La flor de les històries d'Orient, p. 127, Linia: 12)

(56) $O C$ si (..) se posava una moscha en la cara,

If REFL+put.PAST.3 a fly in the face

asò era un tant escàndol

DEM.Neut be. PAST. a big outrage

'(He/she) found it an outrage to have a fly in her face.'

(Corbatxo, p. 58)

(57) $O C$ So

és que una veguada (..) se esdevench

que $(\ldots)$

DEM.Neut be.PRES.3 that a time

REFL+happen.PAST.3 que $(. .$.

that

'Once upon a time it happened that ...'

(Corbatxo, p. 58)

According to Diessel, it is probable that exophoric uses are the basis of all other pragmatic uses of demonstratives. The identification of an object in the surrounding situation of the speech act evolves to an identification of two elements in the discourse. The relationship between the Demonstrative and the element presented by it is clearly one of identification. ${ }^{35}$ One may ask

34. See Diessel (1999: 123-125).

35. We cannot go into the analysis of the pragmatic use of demonstratives. Cf. Diessel (1999, 2006, and references therein). 
which syntactic structure corresponds to that of pragmatic identification. We will not pursue the question of the semantic and pragmatic interpretation of demonstratives, but we will explore the possibilities of explaining the syntactic relationship of the (apparent) expletive and expressive use of demonstratives introducing clauses in Old Romance in a Hale \& Keyser's framework. We will introduce the main intuitions about this relationship and sketch a possible structure.

Specifically, we will argue that the principles that these authors developed in order to answer the questions in (58) and to set up a well-articulated and explanatory theory of predication and argument structure can also explain why (Neuter) demonstratives and personal pronouns appear in sentence initial position with an apparent expletive meaning, deriving later on in an expressive meaning.

(58) a. Why are there so few thematic roles?

b. Why the UTAH? ${ }^{36}$

We propose that the relationship between the demonstrative and the sentence is one of central coincidence in the sense of Hale \& Keyser (1993: 62; 2002, Ch.7). ${ }^{37}$ We build our analysis on H\& K's analysis of stativity and «copular» verbs. Consider a sentence like (54). We argue that in (54) the Neuter Demonstrative açò is the subject of an identificational central coincidence relation. This idea receives support from the diachronic formation of complementizers in many languages from ancient pronominal / demonstrative elements (see Campbell 1998/1999, Heine \& Kuteva 2006, Ch. 6, Roberts \& Roussou 2003, Ch. 3,, Batllori \& Suñer 2009, among others). The copula is the verbal shell that encodes the central coincidence relationship..$^{38}$ Moreover, in this sentence, the Demonstrative is an anaphoric ele-

36. Hale \& Keyser (1993: 65).

37. It would also be interesting to explore the hypothesis that the very structure of the Demonstrative be a Figure-Ground relationship, since the base of its meaning is the location of an object into an abstract space defined by the distance to the speaker / hearer. Gutiérrez-Rexach (2002), mentions the problems adduced by Bennett (1978) to the idea that «regular demonstratives are spelled out as the combination of a definite expression and a locative deictic: this is 'the object here', and that is 'the object there'. Following this idea, the solution can only be that the demonstrative properly is only the location; if not, demonstratives «would be referring to two entities». For this reason, Gutiérrez-Rexach pursues another line of semantic explanation for the meaning of demonstratives. The Figure - Ground structure for demonstratives is lexically transparent in French items like ceci, celà, celui-ci, celui-là, etc. and is also on the basis of the diachronic evolution of Catalan demonstratives aquest (<ECCU-ǏSTE 'here-this-one'), aquell (<ECCU-ǏLLE), 'here-that-one'). Philologists as Dauzat, Dubois \& Mitterand (1968) or Grevisse \& Goosse (2008) have pointed to this twofaced constituency of demonstratives. The lexical object resulting would later on enter into another relationship with the referring nominal. This topic goes far beyond the limits of this paper, and we leave it for further investigation.

38. In fact, one may consider the copula and the Demonstrative as two ways of lexically encoding the $<\mathrm{cc}>$ relationship. Even more, in many languages copulas have developed from demonstratives and personal pronouns «with the mechanism of change involving a reanalysis of a topic-comment construction. (Li \& Thompson (1977: 419). In Chinese, e.g., «the topic-comment construction without a copula became a subject predicate construction with the anaphoric demonstrative pronoun 
ment, which is discourse linked to (some constituent of) the previous sentence. Therefore, the real identification of full semantic elements is between the small clause lo cor tan batent and the predication gran meravella. We would like to suggest that both the expletive and the emphatic value are due to the anaphoric value. From one side, Catalan being a NSL, the Dem can be omitted, since it does not add any new information. From the other side, its properties as a discourse-linked element, and therefore, as a resumption of a previously introduced information, serves to call the attention from the hearer to this discourse antecedent.

There is one predicative relationship between [això] and [era costuma]. Once this constituent is formed, it enters into a second predicative relationship with the embedded sentence [que despertaven los ferres]. We can represent it as in (59), where $<\mathrm{cc}>$ stands for preposition of central coincidence:

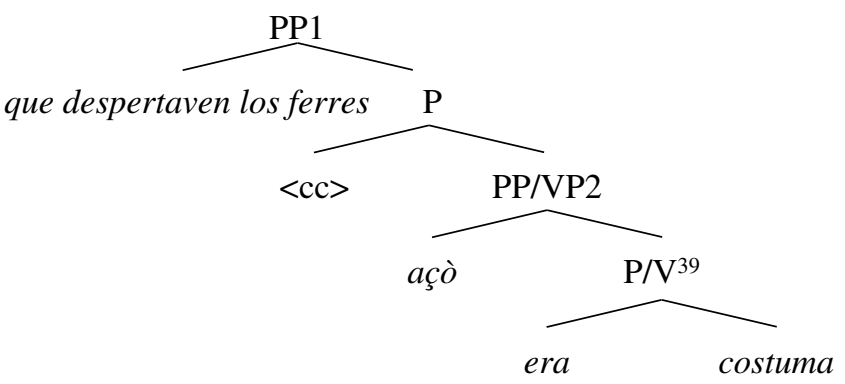

The representation in (59) makes clear that there is a double identificational or predicational relation: one between the predicate costuma and the anaphoric element, and another one between this predication and a sentential subject. It reflects the fact that the sentence is a subject and costuma is the predicate, and that they are mediated by the demonstrative. There are tree elements of a $<\mathrm{cc}>$ meaning: the abstract $\mathrm{P}$, the demonstrative, and the copular verb. The copular verb is needed to bear the T-features and morphemes licensed by $\mathrm{T}$. Therefore, one can expect the demonstrative to become an expletive element, which later on will disappear. At this point, we would like to keep separated in our analysis the informational content of the sentence (thematic vs. rhematic information) from the pure predicative relationship. As has been made clear in the literature, especially by Moro (1997), there is no clear correspondence between the position of a constituent and its status as a subject or predicate in an identificational copular sentence, since predicative DPs can raise to a preverbal position. Another possible analysis is represented in (60):

shi_serving as the copula» (Ibid. 424). The Hebrew clitic form $h u$ is also sometimes analysed as a copula (but see Doron (1986), for another view).

39. We have to explain the somewhat strange notation P/VP. We would like to indicate in a simplified way the following facts: (a) copular equative sentences establish a central coincidence relation between two entities; (b) Ps are the relational categories that encode the central coincidence relationship; (c) the verb $<\mathrm{BE}>$ is a verbal shell that contains this relation. 
(60)

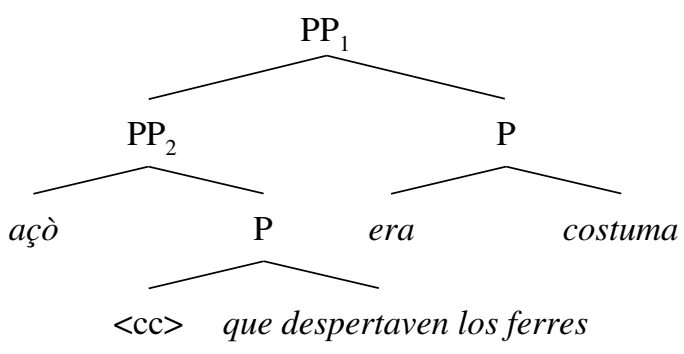

The structure in (60) represents in a clearer way the fact that the embedded sentence is the subject of costuma, even if embedded into another identificational relationship. This $\mathrm{PP}_{2}$ will remain across time after the disappearance of the expletive.

We propose that ELLO bears the same syntactic relationship to the sentence as the demonstrative: one of central coincidence. Therefore, there is a predicative relationship between ELLO and the sentence. The difference is that in these constructions the copula is not mandatory ${ }^{40}$.

(61) a. [[ELL] $[<\mathrm{cc}>$ [no hi ha pa]]]

b.

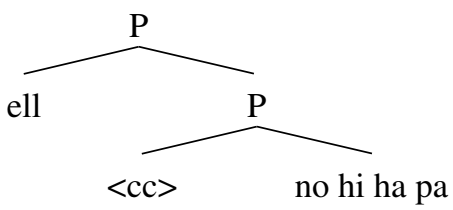

We suggest that ELLO maintains a D-linked relationship to a previous intervention in a discourse, or, more specifically, in a dialog. This fact renders clear its anaphoric value. The straightforward examples from the introduction are repeated here as (62) and (63):

(62) - Madò Paula, parau taula.

Miss Paula set table

- Macià, ell no hi ha pa.

Macià, ELLO not there has bread

(63) - ¡Tornar-lo! i Ell me'n gordaré com de caure! give-back.it ELLO CL.Acc+CL.Gen keep as from fall.INF

40. In Spanish varieties, the copula is more frequent than in Catalan. 
In both cases, ell clearly brings back the assertion made by the other speaker and introduces another assertion that works as a refutation. ${ }^{41,42}$ Since ELLO co-occurs with several sentence types, it cannot be clearly associated to a specific node in the CP field. As we have seen, Carrilho (2009) argues that ele is internally merged in [Spec, ForceP]. Let us leave this issue open for the time being, while investigating another possibility for which we believe to have empirical evidence. Let us consider the dialogs in (58), (59), or the one in (39), repeated here for convenience:

$$
\begin{gathered}
\text { EP -Vás trabalhar? - } \quad \text { Ele não!43 } \\
\text { go-PRES.sg work-INF EXPL NEG } \\
\text { 'Are you going to work? -No!' }
\end{gathered}
$$

In (64), the meaning of ell is always that of negating the previous presupposition with which it is related. ${ }^{44}$ Summing up, ell in BC and ele and in EP generally appear in the second replica of a dialog, clearly referring to the previous assertion, and preceding the new information that the second speaker introduces to contradict the presupposition's or expectations of the first speaker. In that sense, this element has a Discourse Linking property by which the contrastive value implies a polarity and a truth-value opposed to that explicitly set by the previous replica or implicitly presupposed in the previous context. ${ }^{45}$

Under the predicative analysis we defend, ${ }^{46}$ it could also be argued - at least for existential and other impersonal sentences like the one in example (62) - that one discourse property of ELLO is to turn a thetic judgement into a categorical one, $E L L O$ being the discourse subject of the sentence.

The meaning of ELLO does not fit with the notion of Focus or the notion of Topic, and we can also question that it is the Spell-out of ForceP, since it coexists in many languages with several types of sentences. Therefore, we will propose that the semantic-pragmatic value of $E L L O$ - at least in its Left Peripheral expres-

41. This value as a D-linked element used to introduce a new assertion, usually a refutation, would open the possibility to consider it as an evidentiality marker (Aikhenwald (2004), Speas (2004)). We discard this interpretation since there is no narration or reported speech at play, but the speaker's attitude towards the previous assertion.

42. The neuter demonstrative això can also convey this contrastive value, mainly inside idiomatic prepositional phrases like per això, això rai, això i això, a. o. (See Alcover \& Moll, s.v. això)

43. Compare the value of ELLO in these sentence to that of the present day's Spanish pues, or the most colloquial pues va a ser que, this last one always in a negative context :

(i) $-\mathrm{Me} \quad$ prestas $\quad$ los $20 €$ ?

me.Dat lend.PRES. 2 the $20 €$

'Will you lend me those $20 €$ ?'

-Pues (va a ser que) no!

now (it-goes to be that) not

'I'm afraid not.'

44. The Negative context makes the adversative or concessive meaning follow naturally.

45. Interestingly enough, Haegeman (2008) and Haegeman \& Van de Velde (2008: 173) advocate for a similar interpretation for West Flemish tet.

46. In a minimalist Phase-based approach, Gallego (2007:228 and ff.) argues for a contextual interpretation of Focus and Topic subjects. 
sive value - corresponds to the notion of contrast of Molnár (2001) and Molnár \& Winkler (2009). This element shows topic as well as focusing or pointing properties. Following Molnár \& Winkler (2010), contrast has a dual character, which they synthesise as in (65):

(65) i. Like focus, contrast is a highlighting device operating on alternatives within a restricted set and rendering some kind of new information.

ii. Like topic, contrast plays an important role in information linking and contributes to the integration of the utterance into a larger discourse context. Hence, it is an important coherence-creating device since the set it is operating on is contextually available.

(Molnár \& Winkler (2010: 1396)).

There is, nevertheless, an important difference between the constituents that Molnár \& Winkler analyse as bearing the [+contrast] feature, on one side, and ELLO and the Demonstratives under analysis here, on the other. The main difference lies in the fact that the elements they analyse that have the [+c] feature are primarily externally merged inside $\mathrm{VP}^{47}$ and afterwards moved to the $\mathrm{C}$-domain in order to Probe one unvalued [+c] P-feature of the Left Periphery. Instead, ELLO is not an argument of the VP, it is directly externally merged to the sentence.

Summing up what we have said hitherto, the Neuter Demonstrative as well as ELLO are D-linked elements related to a sentence via an (overt or abstract) central coincidence relator ${ }^{48}$. The fact that the Neuter Demonstrative does not behave exactly the same way as $E L L O$ is due to their intrinsic lexical properties, which are different from one another.

Following Rigau (1988), we argue that strong pronouns have a [+contrast] feature together with its $\varphi$-features [Person], [Gender], [Number], and [Case], specified for different values. Demonstratives, instead, have only [+deictic] or [D-linked] features and are not necessarily contrastive. This is the reason why ELLO can become an element of the $\mathrm{C}$ field, whereas Neuter Demonstratives can only evolve to expletive elements: they never appear as expressive elements of the $\mathrm{C}$ field.

Summing up, in this section we proposed that $E L L O$ and $A C ̧ O$ are [D-Linked] elements, and $E L L O$ also bears the [+contrast] feature. These elements are related to the sentence they introduce by means of a Central Coincidence relator or P.

In the next section, we examine the features of $E L L O$ and Neuter expletive Demonstratives to substantiate their different behaviour in the T-C field.

47. Or $v \mathrm{P}$. This distinction is now irrelevant for our argument.

48. Similar relationships have been discovered in early stages of acquisition. Diessel (2004: 4) describes the properties of the sentence in (i) as in (ii):

(i) Here's a rabbit that I'm painting [Nina 3;0]

(ii) «The sentence consists of a presentational copular clause and a relative clause that is attached to the predicate nominal. Following Lambrecht (1998), I argue that the presentational copular clause is propositionally empty: rather than denoting an independent state of affairs, it functions to establish a new referent in focus position making it available for the predication expressed in the relative clause». 


\section{From expletive subject to the $\mathrm{CP}$ area}

In the previous section, we have sketched a semantic and structural analysis of the relationship between ELLO variants and the sentence in terms of Hale \& Keyser's framework. We supported our analysis on well-established facts about the properties of demonstratives and copulas in different languages.

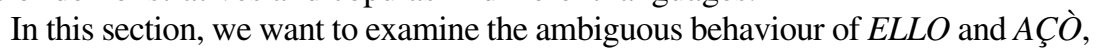
which has led investigators to consider these elements as expletives and as discourse elements belonging to the Left Periphery. It has been noticed that several elements can be argued to ambiguously belong to the $\mathrm{T}$ and to the $\mathrm{C}$ area. As is well known, besides the expansion of the CP area in order to explain the discourse properties of the sentence (Rizzi (1997), (2204)), the fine grained exam of the properties of some subject-like elements has led researchers also to posit the expansion of the TP area (Cardinaletti (2004), Haegeman (2006), (2008)). For our purposes, one interesting element is pleonastic tet in West Flemish. According to Haegeman \& Van de Velde (2008), «Formally, the pleonastic element tet seems to correspond to a strong form of the third person neuter singular pronoun», and appears in sentences like (61):

(66) T'is tet nu an't regenen!

it is tet now on the rain

'It is raining now.'

(Haegeman \& Van de Velde (2008: 160)

Haegeman \& Van de Velde comprehensively analyze the possible merging and landing sites fort tet and its relationship to the (canonical) subject licensing position. The authors discuss several possible analyses existing in the literature for different particles of the subject - modal - peripheral area. They consider Cardinaletti's (2004) analysis of the subject area, under which they propose that tet would belong to the highest projection of the subject field, specifically the Spec of SubjP in the following sequence of possible subject positions:

(67) SpecSubjP - SpecEPP-P - Spec AgrsP ...

Chinellato (2005) also attributes the A-morpheme of Veneto dialects to the IP area. They also put forward the possibility that tet belongs to the $\mathrm{CP}$ area. In the line of Fisher and Alexiadou's (2001) analysis of Fronting in Old Catalan, tet could be a polarity item that lexicalises the $\Sigma$ projection originally proposed by Laka (1990). Hernanz $(2007,2010)$ considers that bien in Spanish, an element that does not have subject-like properties, occupies PolP, a projection from the $\mathrm{CP}$ area with properties similar to $\Sigma \mathrm{P} .{ }^{49}$

It is not our purpose to discuss the well-established arguments in the literature to argue for a split IP and CP area. We will restrict ourselves to anaphoric - con-

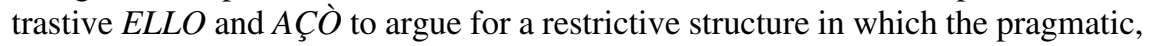
discourse and semantic properties are derived compositionally from the formal features of these elements.

49. For a view of a full developed CP area in Old Romance, see Benincà (2004). 
In the previous section, we argued that $E L L O / A C ̧ O$ is related via an overt or abstract $<\mathrm{cc}>$ preposition to the sentence it introduces. ${ }^{50}$ The lexical features of these elements in the Spec position of the phrase headed by the $<\mathrm{cc}>$ element are responsible of their behaviour as expletives or as expressive elements.

Let us consider now the difference in features between ELLO and $A C ̧ O$, and the way we can dispense with dedicated positions for them. We start from the situation in which ELLO or $A C ̧ O$ are non-expletive subjects. Both pronouns, AIXÒ and ELLO, are Neuter. We consider, following Harley \& Ritter (2002), Pomino \& Stark, (2008, 2010), that Neuter elements in Catalan and Spanish lack the Functional projection of Gender (they are no Masculine or Feminine), and (probably) Number (they do not enter in Singular / Plural alternations). Because of this, Neuter elements cannot refer to individuals, but rather to propositions, predicates or events. ${ }^{51}$ We assume that a D element ${ }^{52}$ with no Gender or Number Features is $\varphi$-defective. This is the reason why Neuter Pronouns can only be subjects of certain kinds of predicates. They appear namely with unaccusative presentational or event predicates (pasar, suceder 'happen, occur'), light verbs that lexicalise a central coincidence relationship (ser 'be', estar 'be', suponer 'mean', significar 'imply'), psychological predicates (gustar 'please', molestar 'bother'), copular predicates with an unaccusative adjective (ser evidente 'be evident', ser peligroso 'be dangerous', ser cierto be true'). Both ELLO and AIXÒ have a D-Linked feature. If they are merged into the $v \mathrm{P}$ or VP, they further probe the EPP feature in $\mathrm{T}$, be it by internal merge into Spec TP or by Long Distance Agreement. This behaviour does not differ from an argumental internal subject.

Expletive - expressive ELLO, however, does not merge in VP or $v \mathrm{P}$ (it is not an argument of the V). It is externally merged as the SPEC of a central coincidence (abstract) P which takes the whole TP/IP as its complement. Let us assume with Emonds (1985) and Dubinsky \& Williams (1995) a.o. that P and C have partially common properties. This would mean that in fact merging ELLO or AIXOे to TP by means of $\mathrm{a}<\mathrm{cc}>\mathrm{P}$ is in some sense equivalent to merge $\mathrm{C}$ material to TP. We have argued that $E L L O$ bears a [D-Linked] and a [+contrast] feature ${ }^{53}$. This $\pi$-feature can be probed by $\mathrm{T}$ or in the $\mathrm{C}$ area ${ }^{54}$. Since $E L L O$ is not an argument, it bears no EPP feature, ${ }^{55}$ and is not probed by $\mathrm{T}$. Therefore $\pi$ is probed by $\mathrm{C}$.

As for $A C ̧ O$, we argue that in the sentences under scrutiny it has no [+contrast] feature, it is only [D-Linked]. In fact, the sentence it introduces does not contradict

50. We could also restate this relation in terms of a Relator as in Den Dikken (2006). The main intuition behind the two proposals is the same.

51. This property has been widely recognized: «Languages which have a neuter gender use this gender for reference to entities which do not fall under a nominal concept (the «anominal use»). (Giurgea (2010: 247).

52. We do not commit ourselves to the level of projection of personal pronouns and demonstratives. It is generally assumed in the literature that personal pronouns are $\mathrm{D}^{0}$ elements, whereas demonstratives are $\mathrm{D}^{\mathrm{max}}$ elements (see Giusti $(1997,2001,2002)$.

53. If we strictly follow Molnár and Molnár and Winkler, we could maybe dispense with the [+D-Linked] feature, since the very concept of contrast embraces it. Let us maintain it for the sake of clarity.

54. Remember that strong pronominal subjects are also contrastive in Catalan.

55. Alternatively, we can say that it has no $[v$ Nom $]$ to be probed. 
previous presuppositions: it can simply be a natural follow-up of the assertions in the previous context. Therefore, it only has the identificational value. This is the reason why $A C ̧ O$ is usually introduced via an explicit copular verb, which gives the sentence the form of an equative sentence with Dem as a subject and CP as a predicate. ${ }^{56}$

The alleged twofold behaviour as both an expletive and expressive meaning, together with the fact that both kinds of constructions, the one with expressive $E L L O$ and the one with D-Linked AIXÒ, are very rare, can be explained in a reductionist framework such as Fortuny (2008). Fortuny elegantly argues that some features are assigned «both to a [+clause typing] position (C) and to a [-clause typing] position (Infl).» (Fortuny 2007: 153). C and Infl constitute a discontinuous syntactic pattern. We would argue that the features [+D-Linked] and [+contrast] are instances of this «replication» of features in $\mathrm{C}$ and $\mathrm{T}$ since they both characterize subjects and discourse chunks that cannot initiate a discourse «out of the blue». If a D element is merged as an argument in VP, it is probed by $\mathrm{T}$ and agrees with $\mathrm{T}$. If it is not, it is externally merged to TP and activates the $\mathrm{C}$ area. We assume the principle in (68) for slight different purposes:

(68) Maximize Matching Effects Principle (MMEP)

Instantiate as many type features as possible using the smallest span of structure

(Fortuny 2007: 148 and elsewhere)

We can assume that, besides the situations analysed by Fortuny, $\mathrm{C}$ is not activated if an element has no other $\pi$-feature than the ones that can also be probed in T. This is the case with $E L L O$.

If TP contains a [+contrast] strong pronoun as a subject, then $E L L O$ cannot be probed there and $\mathrm{C}$ has to be activated. If not, $E L L O$ can occupy Spec TP.

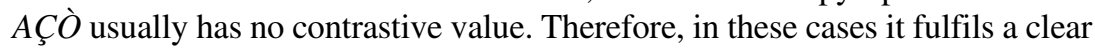
subject function in a copular sentence:

(69) $O C$ Açò era que ...

DEM.Neut be.PAST.3 that

'It was the case that...'

Summing up, the apparent expletive value of ELLO comes from the fact that it usually appears with impersonal sentences. In this kind of sentences, it can probe its features in $\mathrm{T}$. If the sentence contains an argumental subject, the [+contrast] feature of $E L L O$ makes it possible that it is probed by this [+clause typing] feature in C. Otherwise, $\mathrm{C}$ is not activated.

56. It could probably also be argued that the $\mathrm{CP}$ is the subject and $A C ̧ O$ the predicate, since also the predicate can rise (see Moro (1997). We consider however, that discourse properties - the topic value - of demonstratives make our analysis preferable. 


\subsection{An afterthought on the disappearance of these constructions}

We briefly outline two approaches to the question of the disappearance of the constructions under scrutiny.

Given the fact that Neuter ell and Masculine singular ell ara homophonous, according to the Subset Principle, the more specified masculine would be inserted, unless the Neuter form has some additional feature like Force, Polarity or Focus.

The other explanation comes from outside grammar. It could be said that ELLO constructions became unusual since they were difficult to process and decode, namely because of the ambiguity between the Masculine and the Neuter ELLO.

\section{Conclusion}

In this paper, we have revisited the properties of expletive - expressive ELLO and AÇÒ constructions. We have taken into consideration the insights in the previous literature about these elements in several Romance varieties. We discarded an analysis in terms of a grammaticalization process from an expletive subject into a marker or Spell-out of some alleged Left Peripheral category. Instead, we proposed that the properties of ELLO and AÇÒ follow naturally in a compositional way from its lexical and structural properties. We argued that Demonstrative AÇOे and The Neuter strong pronoun ELLO are Discourse-Linked contrastive elements related to the TP by an overt or abstract Central Coincidence P. This means that they belong to the $C$ field. In the spirit of Fortuny's (2007) view that the C field replicates the properties of the $\mathrm{T}$ field, we argued that the features [D-Linked] and [contrast] can be checked in $\mathrm{T}$ or in $\mathrm{C}$, according to the presence or not of an argument subject in the sentence.

\section{References}

Aguiló, Marià (1985). Cançonetes mallorquines recollides per Marià Aguiló. Volum I. Introducció, transcripció i notes per Josep Massot i Muntaner. Barcelona: Barcino. [Biblioteca Folklòrica Barcino, vol. XIX].

Aikhenwald, Alexandra (2004). Evidentiality. Oxford \& New York: Oxford University Press.

Alcover, Joan; Moll, Francesc de Borja $(1951,1968)$. Diccionari Català-ValenciàBalear. Palma de Mallorca: Ed. Moll. http://devb.iec.cat/

Baretti, Joseph (1778). A Grammar of the Italian Language with a copious Praxis of Moral Sentences, to which is added An English Grammar for the Use of Italians. London: W. Strahan \& al. Some pages av. in: http://books.google.com/books/rea der?id=WYMHAAAAQAAJ\&hl=es\&printsec=frontcover\&output=reader\&pg= GBS.PA45

Barnils, Pere (1502). Vocabolari molt profitos per aprendre Lo Catalan Alamany y Lo Alamay Catalan. Perpinyà: Joan Rosembach.

Bartra-Kaufmann, Anna (2008). «Ell tanmateix és gros, això!: un hàpax o una gramaticalització regular?». Workshop de sintaxi diacrònica. Paper presented at UAB, Centre de Lingüística Teòrica, 28/11/2008. 
Batllori, Montserrat; Suñer, Avel-lina (2009). «Universales llingüísticos e itinerarios del cambio: la formación de nexos complejos románicos». In: Rafel Cufí, Joan (ed.). Diachronic Linguistics. Girona: Documenta Universitaria, pp. 299-319.

Belletti, Adriana (1988). «The Case of Unaccusatives». Linguistic Inquiry 19: 1-34.

Benincà, Paola (2004). «The Left Periphery of Medieval Romance». Studi Linguistici e Filologici Online 2.2: 243-297.

Benincà, Paola; Munaro, Nicola (2010). Mapping the Left Periphery. Oxford and New York: Oxford University Press.

Campbell, Lyle (1998/1999). Historical Linguistics: An Introduction. Cambridge, Mass.: The MIT Press.

Cardinaletti, Anna (2004). «Toward a cartography of subject positions». In: Rizzi, Luigi (ed.). The structure of CP and IP. Oxford and New York: Oxford Universituy Press, pp. 115-165.

Cardinaletti, Anna; Repetti, Lori (2010). «Preverbal Vowels in Wh-Questions and Declarative Sentences in Northern Italian Piacentine Dialects». In: Colina, Sonia; Olarrea, Antxon; Carvalho, Ana Maria. (eds.). Romance Linguistics 2009: Selected Papers from the 39th Linguistic Symposium on Romance Languages (LSRL 39). Amsterdam and Philadelphia: John Benjamins, pp. 353-368.

Carrilho, Ernestina (2003). «Construçôes de expletive visível em português europeu (nâo-padrâo)». In: Veiga, Alexandre. Gramática e lexico em sincronia e diacronia. Um constributo da linguistic portuguesa. Universidade de Santiago de Compostela, pp. 29-38.

Carrilho, Ernestina (2005). Expletive ele in European Portuguese Dialects. Ph.D. Diss, Universidade de Lisboa. Available at http://www.clul.ul.pt/en/researcher/129ernestina-carrilho

Carrilho, Ernestina. (2010). 'Explétifs et force illocutoire dans des langues romanes à sujet nul', XXVIe Congrés de Lingüística i Filologia Romàniques, Univ. Valencia, September 2010. PPT available at http://www.clul.ul.pt/en/researcher/129-ernestina-carrilho

Chinellato, Paolo (2005). «Lexicalising functional heads in the 'AgrS-field': evidence form (sic) the 'A-morpheme' in Veneto dialects». University of Venice Working Papers in Linguistics 15: 7-48.

Coromines, Joan (1982). Diccionari etimològic i complementari de la llengua catalana. Barcelona: Curial.

Dauzat Albert; Dubois, Jean; Mitterand, Henri (1967). Nouveau Dictionnaire Etymologique. Paris: Larousse.

Den Dikken, Marcel (2006). Relators and Linkers: The syntax of predication, Predicate Inversion, and copulas. Cambridge, Mass.: The MIT Press.

Diessel, Holger (1999). Demonstratives. Form, Function, and Grammaticalization. Amsterdam: John Benjamins. [Typological Studies in Language, 42]

Diessel, Holger (2004). The acquisition of complex sentences. Cambridge: Cambridge University Press.

Diessel, Holger (2006). «Demonstratives, joint attention, and the emergence of grammar». Cognitive Linguistics 17-4: 463-489.

Doron, Edith (1986). «The Pronominal 'Copula' as Agreement Clitic». In: Borer, Hagit (ed.). Syntax and Semantics, 19. The Syntax of Pronominal Clitics. Orlando \& al.: Academic Press, pp. 313-332. 
Dubinsky, Stanley; Williams, Kemp (1995). «Recategorization of prepositions as complementizers». Linguistic Inquiry 26: 125-137.

Embick, David (2008). «Variation and Morphosyntactic Theory: Competition Fractionated». Language and Linguistics Compass 2/1: 59-78.

Embick, David; Marantz, Alec (2008). «Architecture and blocking». Linguistic Inquiry 39-1: 1-53.

Emonds, Joseph (1985). A Unified Theory of Syntactic Categories. Dordrecht: Foris.

Esteve, Joan (1489). Liber elegantiarum. Venècia, Paganinus de Paganinis. Ed. Facsímil amb estudi preliminar de Germà Colón Domènech. Castelló de la Plana: INCULCA, 1988.

Faarlund, Jan Terje (1990). Syntactic Change. Toward a Theory of Historical Syntax. Berlin-New York: Mouton. [Trends in Linguistics, Studies and Mongraphs, 50]

Fernández Soriano, Olga (1999). «El pronombre personal. Formas y distribuciones. Pronombres átonos y tónicos». In: Bosque, Ignacio; Demonte, Violeta (dirs.). Gramática descriptiva de la lengua española 1: 1209-1273. Madrid: Espasa.

Ferrer, Andreu (1914/ 1974/1999). Rondaies de Menorca. Ciutadella: Nura.

Fornaciari, Raffaello (1881). Sintassi italiana dell'uso moderno. Firenze: Sansoni, Ristampa anastatica, 1974.

Fortuny, Jordi (2007). The emergence of Order in Syntax. PhD. Diss. Barcelona: Universitat de Barcelona.

Gallego, Angel J. (2007). Phase Theory and Parametric Variation. Ph.D. Diss. Bellaterra: Universitat Autònoma de Barcelona.

Giurgea, Ion (2010). «Romanian genderless pronous and parasitic gaps». In: Colina, Sonia; Olarrea, Antxon; Carvalho, Ana Maria (eds.). Romance Linguistics 2009: Selected Papers from the 39th Linguistic Symposium on Romance Languages (LSRL 39). Amsterdam and Philadelphia: John Benjamins, pp. 230-248.

Giusti, Giuliana (1997). «The categorical status of determiners». In: Haegeman, Liliane (ed.). The New Comparative Syntax. London: Longman.

Giusti, Giuliana (2001). «The birth of a functional category: From Latin Ille to the Romance article and personal pronoun». In: Cinque, Guglilemo; Salvi, Gian Paolo (eds.). Current Studies in Italian Syntax. Essays offered to Lorenzo Renzi. Oxford: Elsevier, pp. 157-171.

Giusti, Giuliana (2002). «The functional structure of noun phrases. A bare structure approach». In: Cinque, Guglielmo (ed.). Functional Structure in DP and IP: the cartography of syntactic structures, vol.1. Oxford: Oxford University Press, pp. 54-90.

Grevisse, Maurice; Goose, André (2008). Le bon usage. Bruxelles: De Boeck Université (14e édition).

Gutiérrez-Rexach, Javier (2002). «Demonstratives in Context». In: GutiérrezRexach, Javier (ed.). From words to discourse: Trends in Spanish Semantics and Pragmatics. Oxford: Elsevier, pp. 195-236.

Gries, Stefan Th. (2010). «Corpus linguistics and theoretical linguistics. A love-hate relationship? Not necessarily...». International Journal of Corpus Linguistics 15-3: 327-343.

Haegeman, Liliane (2006). «Conditionals, factives and the left periphery». Lingua 116: 1651-1669.

Haegeman, Liliane (2008). «Pleonastic tet in West Flemish and the Cartography of Subject Positions». In: Barbiers, Sjef; van der Ham, Margreet; Koeneman, Olaf; 
Lekakou, Marika. Microvariations in Syntactic Doubling. Syntax and Semantics 36: 277-290.

Haegeman, Liliane; Van de Velde, Danièle (2008). «Pleonastic tet in the Lapscheure dialect». Catalan Journal of Linguistics 7: 157-199.

Hale, Ken; Keyser, Samuel Jay (1993). «On argument structure and the lexical expression of syntactic relations». In: Hale, Ken; Keyser, Samuel Jay (eds.). The view from Building 20: Essays in linguistics in honor of Sylvain Bromberger. Cambridge, Mass.: MIT Press, pp. 53-109.

Hale, Ken; Keyser, Samuel Jay (2002). Prolegomena to a Theory of Argument Structure. Cambridge, Mass.: MIT Press.

Halle, Morris; Marantz, Alec (1993). «Distributed Morphology». In: Hale, Ken; Keyser, Samuel Jay (eds.). The View from Building 20. Cambridge, Mass: MIT Press, pp. 111-176.

Harley, Heidi; Ritter, Elizabeth (2002). «Person and number in pronouns: a featuregeometric analysis». Language 78-3: 482-526.

Heine, Bernd; Kuteva, Tania (2006). The Changing Languges of Europe. Oxford /New York: Oxford University Press.

Heine, Bernd; Song, Kyung-An (2011). «On the grammaticalization of personal pronouns». Journal of Linguistics 7-03: 587-630. We quote the previous publication online, appeared March, 2011. (doi: 1017/S0022226711000016).

Henríquez Ureña, Pedro (1939). «Ello». Revista de Filología Hispánica 1-3: 209-229.

Hernanz, Maria Lluïsa (2007). «From polarity to modality: Some (a)symmetries between bien and sí in Spanish». In: Eguren, Luis; Fernández Soriano, Olga (eds.). Coreference, Modality, and Focus. Studies on the syntax-semantics interface. Amsterdam, John Benjamins, pp. 133-169.

Hernanz, Maria Lluïsa (2010). «Assertive Bien in Spanish and the Left Periphery». In: Benincà, Paola; Munaro, Nicola (eds.). Mapping the Left Periphery. The Cartography of Syntactic Structures, Volume 5. Oxford /New York: Oxford University Press, pp. 19-62.

Hinzelin, Marc-Olivier (2006). «Die neutrales Pronomina 'ell', 'això', 'allò', 'açò', und 'ço' in unpersöhnlichen Konstruktionen in diachroner und dialektaler Variation». In: Push, Claus D. (ed.). La gramàtica pronominal del català: variació - evolució - funció / The grammar of Catalan pronous: variation - evolution - function. Aachen: Shaker Verlag, pp. 46-84. [Biblioteca Catalànica Germànica - Beihefte zur Zeitschrift für Katalanistik]

Hinzelin, Marc-Olivier (2009). «Neuter pronouns in Ibero-Romance: Discourse reference, expletives and beyond». In: Kaiser, G.A.; Remberger E.M. (eds.). Proceedings of the Workshop «Null-subjects, expletives, and locatives in Romance». Arbeitspapier 123, Fachbereich Sprachwissenschaft, Universität Konstanz 2009, pp. 1-25.

Hinzelin, Marc-Olivier; Kaiser, Georg. (2006). 'Das neutrale Pronomen ello im dominikanischen Spanisch und die Nullsubjekteigenshaft. Anhang: Korpus und Bibliographie zu ello und unpersönlichen Konstruktionen (mit Subjekt) im Spanischen'. Fachbereich Sprachwissenschaft der Universität Kostanz. Arbeitspapier Nr.116. Disponible a http://www.ub.uni-konstanz.de/kops/volltexte/2006/2223/.

Kaiser, Georg A. (2006). «Pronombres sujeto en construcciones impersonales de lenguas iberorrománicas». In: Fernández Fernández, Beatriz; Laka Mugarza, Itziar (eds.). Andolin gogan. Essays in honour of Professor Eguzkitza. Euskal Herriko 
Unibersitatea, pp. 513-530. http://ling.uni-konstanz.de/pages/home/kaiser/files/ Kaiser2006_Pronombres.pdf

Kroch, Anthony (1989). «Reflexes of Grammar in Patterns of Language Change». Language Variation and Change, 1: 199-244.

Kroch, Anthony (2001). «Syntactic change». In: Baltin, Mark; Collins, Chris (eds.). Handbook of Syntax. Oxford: Blackwell, pp. 699-729.

Laka, Itziar (1990). Negation in Syntax: on the nature of functional categories and projections. PhD. Dissertation, MIT (Distributed by MIT Workinh Papaers in Linguistics).

Lapesa, Rafael (1996). «El español de América». Available at http://www.elcastellano. org/america8.html

Li, Charles N.; Thompson, Sandra A. (1977). «A Mechanism for the Development of Copula Morphemes». In: Li, Charles N. (ed.). Mechanisms of Syntactic Change. Austin \& London: University of Texas Press, pp. 419-444.

Lightfoot, David (1999). The development of language: Acquisition, change and evolution. Blackwell: Oxford.

Longa, Víctor M.; Guillermo Lorenzo; Rigau, Gemma (1998). «Subject clitics and clitic recycling: locative sentences in some Iberian Romance languages», Journal of Linguistics 34: 125-164.

Manente, Mara (2007). «On the locative component of French weather-ça». Probus 19: 75-91.

Massanell Messalles, Mar (2009). «Beneficios de los corpus informatizados para la investigación diacrónica: el caso del CICA para la GCA y los auxiliares de perfecto». In: Romero, Laura; Julià, Carolina (coords.). Tendencias actuales en la investigación diacrónica de la lengua. Barcelona: Edicions i Publicacions de la Universitat de Barcelona, pp. 147-158.

Mayol, Laia (2010). «Contrastive Pronouns in Null Subject Romance Languages». Lingua 120(10): 2497-251.

McFadden, Thomas (2010). «Why some things in diachronic syntax can only be done with corpora». HO of a paper presented at The Syntax Circle, Merteens Institut, may 26th., 2010. Available at http://www.hum.uit.no/a/mcfadden/papers.html

Migliorini, Bruno (1966). The italian language. Abridged and recast by T. Gwynfor Griffith. London: Faber \& Faber.

Moll, Francesc de B. (1982). Textos i estudis medievals. Pròleg d'Antoni M. Badia i Margarit, AILLC, Fundació Congrés de Cultura Catalana, P.A.M. Part III. L'obra de Joan Esteve (El «Liber elegantiarum» 247-280 (Conferència publicada per la UB, 1961); Entorn del lèxic del «Liber elegantiarum» 281-306 (Publicat a les Actes del Quart Col-loqui Internacional de Llengua i Literatura catalanes, Montserrat 1977, 117-140); Els sons i les forms en el «Liber elegantiarum» 307-315) Publicat a Romanica Europaea et Americana. Festschrift für Harri Meier, 8 Jaunuar 1980, Bonn, 386-391).

Molnár, Valéria (2001). «Contrast from a Contrastive Perspective». Paper presented at the ESSLLI 2001 Workshop on Information Structure. Discourse Structure and Discourse Semantics. Available at http://www.coli.uni-saarland.de/ korbay/ esslli01-wsh/Proceedings/11-Molnar.pdf

Molnár, Valéria; Winkler, Susanne (2009). «Edges and Gaps: Contrast at the Interfaces». Lingua 120.6: 1392-1415. 
Moro, Andrea (1997). The raising of predicates. Predicative noun phrases and the theory of clause structure. Cambridge, New York and Melbourne: Cambridge University Press.

Munaro, Nicola (2005). «Grammaticalization, Reanalysis, and CP Layering». In: Batllori, Montserrat; Hernanz, M. Lluïsa; Picallo, M. Carme; Roca, Francesc (eds.). Grammaticalization and Parametric Variation. New York: Oxford University Press, pp. 29-47.

Munaro, Nicola; Poletto, Cecilia (2003). «Sentential particles and clausal typing in the Veneto dialects». University of Venice Working Papers in Linguistics 13: 127-154.

Paoli, Sandra (2007). «The fine structure of the left periphery: COMPs and subjects. Evidence from Romance». Lingua, 117: 1057-1079.

Pintzuk, Susan (2003). «Variationist approaches to syntactic change». In: Joseph, B.D.; Janda, R. (eds.). The handbook of historical linguistics. Oxford: Blackwell Publishing, pp. 509-528.

Poletto, Cecilia (2000). The higher functional field: evidence from northern Italian dialects. Oxford: Oxford University Press.

Pomino, Natasha; Stark, Elisabeth (2008). «Sobre los demostrativos 'neutros' en español: esto, eso y aquello». In : Company Company, C.; Moreno de Alba, J.G. (eds.). Actas del VII Congreso Internacional de Historia de la Lengua Española. Madrid: Arco Libros, pp. 943-965.

Pomino, Natasha; Stark, Elisabeth (2009). «Losing the 'neuter': the case of the Spanish demonstratives». Probus 21: 217-247.

Raposo, Eduardo; Uriagereka, Juan (1990). «Long-Distance Case Assignment». Linguistic Inquiry 21.4:505-537.

Remberger, Eva-Maria; Hinzelin, Marc-Olivier (2009). «Expletive vs. discourse marker: Sardinian ello and Balearic Catalan ell». H.O. of a paper presented at the XXXVII Romance Linguistics Seminar, Trinity Hall, Cambridge, 5-6 January, 2009.

Richards, Marc; Biberauer, Teresa (2005). «Explaining Expl». In: den Dikken, Marcel; Tortora, Christina M. (eds.). The Function of Function Words and Functional categories. Amsterdam /Philadelphia: John Benjamins, pp. 115-153. [Linguistik Aktuell, 78].

Rigau, Gemma (1988). «Strong Pronouns». Linguistic Inquiry 19.3: 503-511.

Rinke, Esther; Elsig, Martin (2010). «Quantitative evidence and diachronic syntax». Lingua 120: 2557-2568.

Rizzi, Luigi (1997). «The fine structure of the left periphery». In: Haegeman, Liliane (ed.). Elements of Grammar. Berkeley: Kluwer, pp. 281-337.

Rizzi, Luigi (ed.) (2004). The Structure of CP and IP. The Cartography of Syntactic Structures, vol.2. Oxford and New York: Oxford University Press.

Roberts, Ian; Roussou, Anna (2003). Syntactic Change: A Minimalist Approach to Grammaticalization. Cambridge: Cambridge University Press.

Silva-Villar, Luis (1998). «Subject positions and the roles of CP». In: Schweger, Armin; Tranel, Bernard; Uribe-Etxebarria, Miriam (eds.). Romance Linguistics. Theoretical Perspectives. Selected Papers from the 27th Linguistic Symposiu on Romance Languages (LSRL XXVII), Irvine, 20-22 February, 1997. Amsterdam: John Benjamins, pp. 247-270.

Silva-Villar, Luis (2004). «Growing expletives». Abstract of a paper presented at the Colloquium on Expletive Subjects in Romance and Germanic Languages. 
Universität Konstanz, SFB 471, Projekt A19. November 11-13, 2004. Organized by Georg A. Kaiser \& Marc-Olivier Hinzelin. Available at http://ling.uni-konstanz. de/pages/home/kaiser/sfb/pdf/koll_brosch.pdf

Speas, Margaret (2004). «Evidentiality, logophoricity and the syntactic representation of pragmatic features». Lingua 114: 255-276.

Stark, Elisabeth; Pomino, Natasha (2010). «How the Latin neuter pronominal forms became markers of non-individuation in Spanish». In: Stathi, Ekaterini; Gehweiler, Elke; König, Ekkehard (eds.). Grammaticalization: Current views and issues, pp. 273-294.

Toribio, Almeida Jaqueline (1996). «Dialectal variation in the licensing of null, referential and expletive subjects». In: Parodi, Claudia; Quicoli, Carlos; Saltarelli, Mario; Zubizarreta, Maria Luisa (eds.). Aspects of Romance Linguistics. Selected Papers from the Linguistic symposium on Romance Languages XXIV. March 10-13, 1996. Washington: Georgetown University Press, pp. 409-432.

van Gelderen, Elly (2004a). «Specifiers, Heads, Grammaticalization, and Economy». Journal of Comparative Germanic Linguistics 7.1: 59-98.

van Gelderen, Elly (2004b). Grammaticalization as Economy. Amsterdam: John Benjamins. [Linguistik Aktuell, 71].

van Gelderen, Elly (2006). «Economy of Merge and Grammaticalization: Two steps in the Evolution of language». Msc. Available at http://www.public.asu.edu/ gelderen/ pub.htm

van Gelderen, Elly (2008). «Where did late merge go? Grammaticalization as feature economy». Studia Linguistica 62(3): 287-300.

Veny, Joan. (1999). Aproximació al dialecte eivissenc. Mallorca: Ed. Moll [Col-lecció Tomir, 40].

\section{Databases}

CICA: http://lexicon.uab.cat/cica/index.php CORDE: http://corpus.rae.es/cordenet.html 